\title{
GÁBOR GÁNGÓ
}

Institute of Philosophy, Research Centre for the Humanities

\section{Stanisław Brzozowski and Die Neue Zeit}

Stanisław Brzozowski's contribution to Die Neue Zeit (The New Times), the theoretical journal of the Social Democratic Party of Germany (SPD), Der Geschichtsmaterialismus als Kulturphilosophie: Ein philosophisches Programm (Historical Materialism as Philosophy of Culture: A Philosophical Project), has been long-known to scholars (Walicki 2011a. 124, 365-366, 405; Politt 1996. 155). The original Polish version, which was published in Przeglad Spoleczny (Social Review) and in Brzozowski's book Idee (Ideas), has been subject to intensive analysis. In this paper, I will argue that although the German version of the article does not considerably enrich Brzozowski's work from a strictly thematic point of view, it cannot be dismissed as a re-issue either. The circumstances of its publication in Die Neue Zeit do help us to understand Brzozowski's intellectual and political dilemmas, especially in regards to his personal relationship with German and Polish Social Democracy between the Russian Revolution of 1905 and the outbreak of the "Brzozowski affair" in early 1908, when he abruptly abandoned all efforts to gain an international reputation. Thus, this article challenges the commonly held view on the lamentable ignorance of Brzozowski outside of Polish literature through the contextual reconstruction of the story of his sole appearance in the most important forum of German Social Democracy. ${ }^{1}$

* First published In Jens Herlth - Edward M. Świderski (eds.) Stanisław Brzozowski and the Migration of Ideas. Transnational Perspectives on the Intellectual Field in Twentieth-Century Poland and Beyond. Bielefeld, transcript Verlag. 2019. 57-76.

${ }^{1}$ Concerning Brzozowski's international reputation, it must be noted that his novel, Ptomienie (Flames), was published posthumously by Bong Verlag in 1920 in a German translation, Flammen (Brzozowski 1920). Richard Bong (1853-1935) was a woodcut printmaker in Berlin who founded his publishing house in 1891 (Kempe s. a.). Besides art books, he also published books by and on Richard Wagner, William Shakespeare, among others. Leon Richter, Brzozowski's translator, also translated Władysław Stanisław Reymont's novel Wampir (The Vampire), which came out in 1914. Further research about the reception of Flammen in the interwar German and East European Zionist youth move- 


\section{Die Neue Zeit: A Forum for Marxist Theory and Polish Social Democracy}

At the time of Brzozowski's interest in the journal, Die Neue Zeit was the main organ for the international Social Democratic movement (Emig-Schwarz-Zimmermann 1981. 85), which remained from its very beginning under the editorial management of Karl Kautsky until 1917, (Graf 1998. 96-102; Schelz-Brandenburg: Introduction to Die Neue Zeit). The profile of the journal was revamped several times with its main profile being the broadening of sociology as scientific support for the routine struggle in the labour movement. It encompassed such themes as the women question, colonization, the living conditions of the working class, modernization, discoveries in natural sciences and technology, healthcare, industry and capitalism, Russia, contemporary naturalistic and socially engaged novels, the economy, alcoholism, prostitution, and periodical overviews of the workers' movement in various European countries, including the Polish movement as part of or connected to the Russian, German, and Austrian Social Democracy.

After Die Neue Zeit became increasingly involved in the fate of German Social Democracy, it equally grew more open to the application of theoretical issues. When Brzozowski's study was published, the journal was a general philosophical forum of the Left, so they included a number of authors who contributed but did not belong to the core group of contributors to the journal. Despite this, Brzozowski was the only one audacious enough to challenge the orthodox interpretation of historical materialism.

After 1890, Die Neue Zeit became an important forum for Polish Social Democracy as Polish authors and subjects concerned with it started to appear regularly; articles from the journal were translated for the Polish socialists as well (for example: Kwestja 1905). These articles generally reported on the situation of socialism in Poland for the labour movements in Germany, Russia, and Austria. Such Polish authors from around the turn of the century included Kazimierz Kelles-Krauz, who discussed theoretical issues from a Polish perspective, and Salomea Perlmutter, who wrote articles for the journal and, along with this, a review of her dissertation was published as well (Perlmutter 1903; 1905; Zetterbaum 1903a). Besides her articles, a letter of hers to Kautsky that was sent along

ments is still missing in Brzozowski scholarship, although significant contributions are available for scholars speaking Hebrew (cf. Nordheimer-Nur 2009. 67-68); concerning Matityahu Mintz's works on the history of Hashomer Hatzair in Poland, see Oppenheimer 2004. 11). According to Yosef Gorny's summarizing account, "the Marxism of Hashomer Hatzair was diluted with the national socialist ideals of Brzozowski" (Gorny 2002). 
with her Ein Beitrag zur Agrarfrage (A Contribution to the Agrarian Question) also remains (IISH Kautsky D XVIII 486).

Kautsky was moderately interested in Polish issues; at least as far as the problem of the Russian-Polish rivalry was concerned. He wrote two articles on Poland in his journal: Finis Poloniae? (The End of Poland?), which was published in 1895-1896, while Das neue Polen (The New Poland) in 1916-1917 reflected a more optimistic stance towards the reestablishment of the Polish state. The former article argued that St. Petersburg was a more likely revolutionary center than Warsaw so that the international proletariat did not have to stand up for the restitution of Poland. The Russian Revolution of 1905 seemed to fulfil Kautsky's most sanguine hopes ${ }^{2}$ and he encouraged the Polish to integrate with democratic Russia (Tych 1992). Kautsky occupied a definitive pro-Russian stance and he regarded the never-ending skirmish between Polish and Russian Social Democrats as a mutually detrimental and regrettable event for the international workers' movement, ${ }^{3}$ thus he wanted to keep his journal free from these bitter polemics. $^{4}$

Although it had some discussion of Polish issues, Die Neue Zeit was primarily the forum where new trends in Marxism were discussed. From the very beginning, a number of renowned Marxists-many had been long-time activists in the labour movement-contributed to Die Neue Zeit with studies on historical materialism, which played a part in the evolution of Marxist thought. Brzozowski's article was consequently one text among many others, and to add more to his obscurity, he was relatively unknown in the socialist movement.

2 As he wrote in 1905 to an unknown correspondent, "Die russische Revolution macht mich zehn Jahre jünger” (BArch Kautsky NY 4055/11. fol. 60). I would also like to thank Grit Ulrich (Bundesarchiv, Berlin-Lichterfelde) for her help during my research in German State Archives.

3 "Im übrigen kann ich Ihnen nicht verschweigen, daß, so weit ich in Basel über die rußischen Dinge sprechen konnte, ich überall die größte Erbitterung und Mißachtung gegen die rußischen und polnischen Genoßen wegen ihres ewigen Haders gefunden habe. [...] Man hat in der Internationale keinen Respekt mehr vor Euch - dieß „Euch” gilt allen Fraktionen" (Karl Kautsky to Julian Marchlewski, Berlin-Friedenau, 9 December, 1912, BArch Kautsky NY 4055/22Ü, fol. 14).

${ }^{4}$ „Was ich anstrebe, ist von der N. Z. jede Diskussion russischer Streitpunkte fernzuhalten. [...] Von diesem Standpunkt aus lehne ich jeden polemischen Artikel über russisch-polnische Streitpunkte ab, stamme er von rechts oder links. Ich mußte auch den Ihren ablehnen" (Karl Kautsky to Julian Marchlewski, Berlin-Friedenau, 13 December, 1912, BArch Kautsky NY 4055/22Ü, fol. 16). 


\section{Brzozowski's Der Geschichtsmaterialismus als Kulturphilosophie. Its Journey to Die Neue Zeit}

At least from the beginning of 1906, Brzozowski wanted to make himself known to the German-speaking world, so he turned to Salomea Perlmutter who later became his translator as well as his mediator for communicating with Kautsky. (For her biography, see Brzozowski 1970. Vol. 1. 107n1; Leszczawski-Schwerk 2014.) First, he was thinking about a text entitled Czy wracamy do Kanta? (Back to Kant?), although there is nothing more that is known about this project (Stanisław Brzozowski to Salomea Perlmutter, Nervi, 7 February, 1906. Brzozowski 1970. Vol. 1. 155). Instead, Perlmutter translated two of his other articles into German and recommended them to Die Neue Zeit and to the Austrian Socialist review Der Kampf (The Struggle) respectively (Brzozowski 1970. Vol. 1. 159n10, 318, 321n1, 354). Der Kampf published his Polnische Literatur in der Revolution (Polish Literature in the Revolution) in January 1908 (Brzozowski 1970. Vol. 1. 338n14).

The Polish version of Historical Materialism as a Philosophy of Culture was published in February 1907 in Przeglad Społeczny and then was translated and sent to Die Neue Zeit by early April. In his commentary to Perlmutter, Brzozowski downplayed the significance of his manuscript and braced himself against Kautsky's rejection. He apologetically wrote to Perlmutter telling her to expect rejection, "artykuł nie był ani dobrze napisany, any nowy w treści. Mniejsza o to zresztą: nie zmartwie się nieuchronną odmową Kautskiego. Szkoda tylko mi Waszego czasu." (The article was neither well-written nor new in its content. Whatever, I do not care about Kautsky's inevitable refusal. But it's a pity for your time.) (Stanisław Brzozowski to Salomea Perlmutter, Nervi, 10 April, 1907. Brzozowski 1970. Vol. 1. 319) He again wrote the same sentiments to the Buber family, "Sądzę, że Kautsky nie wydrukuje artykułu, i będzie miał słuszność" (I assume that Kautsky is not going to publish the article, and he will be right in doing so.) (Stanisław Brzozowski to Wula and Rafał Buber, Nervi, around 10 April, 1907. Brzozowski 1970. Vol. 1. 325).

Brzozowski was probably pleasantly surprised when he received the news of the May 1907 publication of his article and he began formulating projects for further contributions to Die Neue Zeit. He considered writing on the topics of Machiavelli (Stanisław Brzozowski to Salomea Perlmutter, Nervi, 2-3 June, 1907. Brzozowski Vol. 1. 346), the "social foundations of Nietzscheanism", and "contemporary art." His publication was a rite of passage to the working class, which he labeled as his belonging to a "minderwerthiger klasy" ("infe-

5 „Czy dla Neue Zeit nie byłoby dobrze napisać: społeczne podstawy nietscheanizmu [!] lub raczej 'nowej sztuki'?’, Stanisław Brzozowski to Salomea Perlmutter, Nervi, 7 June, 1907 (Brzozowski 1970. Vol. 1. 354). 
rior class") (Stanisław Brzozowski to Salomea Perlmutter, Nervi, 7 June, 1907. Brzozowski 1970. Vol. 1. 353). It reveals a telling analogy of how he viewed the Poles as inferior compared to the Germans, referring to it as the "minderwerthige Nation" in his letter to Wula and Rafał Buber on 4 January 1906 (Brzozowski 1970. Vol. 1. 109).

\section{Brzozowski's Polemic with Karl Kautsky's Ethik und materialistische Auffassung}

In the initial Polish version, Historical Materialism as Philosophy of Culture was a creative effort to reinterpret some fundamental theses of historical materialism with a fearless confidence in the intellectual strength of Polish culture vis-à-vis the German Socialist mainstream; for its contemporary readership, the German translation must have given a very different impact. The reference to the orthodox Marxist interpretation of ethical issues in the first sentence of the article gives the impression that Brzozowski was specifically addressing Karl Kautsky. The beginning surprises the reader with its sharply polemical tone that invokes an "unpleasant" and "thoroughly non-philosophical custom" of using the word "Marxism" as a brand that is fit for all subject matter. As well, it mentions an example for an imaginary title of a book very similar to that of Karl Kautsky's entitled, Ethics and the Materialist Concept of History. Brzozowski writes,

In der sozialistischen wissenschaftlichen Literatur findet sich bisweilen die unangenehme und durchaus unphilosophische Gewohnheit, an allerhand Dinge den Marxismus einem Schilde gleich anzuhängen, das sich ab- und ankleben läßt: „Die Kunst vom marxistischen Standpunkt“, „Die Ethik vom Gesichtspunkt des historischen Materialismus" usw.

In socialist scientific literature one encounters from time to time the unphilosophical habit of attaching all sorts of things to Marxism as if it were a signpost where one could hang something up or take it down: "Art from a Marxist standpoint", "Ethics from a Historical Materialist Perspective", and the like (Brzozowski 1907. 153-154).

Accordingly, the critique of the usual treatment on question of ethics and aesthetics in Marxist literature seems to be directed at Karl Kautsky's book, which had a Polish translation (Kautsky 1906a). ${ }^{6}$

${ }^{6}$ Holger Politt attributes the translation to Jan Władysław Dawid (Politt 1996. 47n27). 
In his book, Kautsky intended to elucidate the difference between Kantian and historical materialist ethics to prove that Kant's position was very far from a Socialist one (Kautsky 1906b. vii, 34), and thus, Kautsky separated ethics from historical materialism. ${ }^{7}$ Brzozowski, in contrast to Kautsky, argues that there is an essential relation between the cultural superstructure and its economic base (Brzozowski 1907. 154). Although he did agree with Kautsky that the ethical ideal had always been and would always remain in the hands of the bourgeoisie (Kautsky 1906b. 135-136), he tried to formulate another solution to this problem by provocatively distinguishing the truth of political socialism with that of philosophical Marxism. While political socialism uses Marxism as its instrument in the struggle for changing society's economic basis, philosophical Marxism is concerned with the method of approaching the superstructure in a Hegelian approach:

Denn der Geschichtsmaterialismus ist nichts anderes als die Methode, alles zu erforschen was das Werk der Menschheit ist, also auch die Mora, das Recht, die Wissenschaft und die Kunst [...]. Der Geschichtsmaterialismus ist das Selbstbewußtsein der geschichtlichen Schöpfungskraft, die aus sich Kunst und Literatur, Wissenschaft, Recht, Moral, Religion und Sozialwirtschaft gebärt [...]. [D]er Geschichtsmaterialismus zeigt uns die Geschichte der Menschheit und deren Kultur, als ihr eigenes selbst geschaffenes Werk und ihre Verantwortlichkeit.

Historical materialism is nothing else than the method to explore everything that is the work of man= that means morals, right, science, and art [...]. Historical materialism is the self-consciousness of the historical creative force issues from art, literature, science, right, morals, religion, and social economy [...]. Historical materialism shows us the history of mankind and its culture as a self-created work and responsibility. (Brzozowski 1907. 154-155.)

7 "Auch die Sozialdemokratie als Organisation des Proletariats in seinem Klassenkampf kann das sittliche Ideal, kann die sittliche Empörung gegen Ausbeutung und Klassenherrschaft nicht entbehren. Aber das Ideal hat nichts zu suchen im wissenschaftlichen Sozialismus, der wissenschaftlichen Erforschung der Entwicklungs- und Bewegungsgesetze des gesellschaftlichen Organismus zum Zwecke des Erkennens des notwendigen Tendenzen und Ziele des proletarischen Klassenkampfes. [...] Die Wissenschaft steht über der Ethik, ihre Resultate sind ebensowenig sittlich oder unsittlich, als die Notwendigkeit sittlich oder unsittlich ist." Kautsky 1906b. 141-142. 
By establishing an analogy between historical materialism and cultural creation on the one hand and natural sciences and technical praxis and discoveries on the other, ${ }^{8}$ Brzozowski modifies Kautsky's approach to the relationship between technical progress and historical materialism. ${ }^{9}$ Brzozowski also argues with Kautsky's interpretation of moral ideals, saying that

Moral, Ästhetik, Kunst, Philosophie, Geschichtsauffassung und Kultur bleiben noch immer unter dem überwiegenden Einfluß der Autoritäten und Ideale, welche der ritterlich-priesterliche Lebens- und Denktypus ausgearbeitet hat. Dieser Typus hatte seine inneren Gegensätze und Zerrissenheiten; der Priester kämpfte hier mit dem Ritter. Und heute noch kämpfen in unseren Köpfen diese Gespenster, die Stelle moderner Kämpfe vertretend. Die Probleme treten eine lange Zeit in historischen, anachronistischen Masken auf, bevor sie in ihrer wahren, nackten Gestalt auftreten.

Morality, aesthetics, art, philosophy, and concepts of history and culture still remain under the predominant influence of authorities and ideals that were produced by the chivalric and priestly way of living and thinking. It has always had its inner contradictions and disunities; the priest always struggled against the knight. Even today these specters still fight in our heads, replacing modern struggles. Problems tend to appear for a long time in historical and anachronistic masks, before appearing in their real, naked shape. (Brzozowski 1907. 159.)

\section{A Further Effort to Strengthen Contacts: Brzozowsi's Letter to Karl Kautsky}

Once Brzozowski received his copy of Die Neue Zeit, he intended to continue his success; the very next day, on 8 June, 1907, he wrote the following letter to Karl Kautsky:

\section{Hochgeehrter Genosse!}

Gestern habe ich die N. der Neuen Zeit erhalten, wo mein Artikel, den meine gute Freundin Genossin dr. Salomea Perlmutter so gütig war zu übersetzen und Ihnen über-

8 „Der Geschichtsmaterialismus ist das im Verhältnis zur kulturellen und historischen Schaffungskraft, was die theoretische Wissenschaft gegenüber der technischen Praxis und der Erfindungskraft” (Brzozowski 1907. 155).

${ }^{9}$ „Kein Zweifel, es besteht eine Wechselwirkung zwischen der Ökonomie und ihrem geistigen Überbau - Moral, Religion, Recht, Kunst usw. -: von dem geistigen Wirken des Erfindens reden wir hier nicht, es gehört zur Technik, in der ja der Geist auch eine Rolle spielt, neben dem Werkzeug; die Technik ist die bewußte Erfindung und Anwendung von Werzeugen durch den denkenden Menschen" (Kautsky 1906b. 128). 
senden. Es freut mich sehr, dass meine Arbeit so günstig von Ihnen beurtheilt war, und lasse mir hoffen dass auch andere meine Beiträge werden von Zeit zu Zeit auf Spalten Neuer Zeit Platz für sich finden[.] Wenn ich aber jetzt mir erlaube Ihnen mit meinem in schlecht deutschen geschriebenen Brief Zeit zu verderben, dann thue ich es um Ihre Aufmerksamkeit auf eine Kleinigkeit zu lenken, die vielleicht einer Besprechung und Abfertigung in Neuer Zeit nicht unwerth ist. In dem neuen Buch von Arturo Labriola uber die Pariser Komune, finde ich folgenden „,geistreichen“ Einfall über Karl Marx. Ich schreibe die Stelle buchstablich ab:

["]Ma il guidizio di Marx è soggetto a revisione. Marx non amò mai i suoi concorrenti socialistici, la qual cosa mentre teneva all'indiscutibile superiorità della sua mente sovrana, rivela in lui una inclinazione poco simpatico dello spirito[.] Successivamente egli si ruppe col Willich, col Weitling, col Proudhon, col Bakunine, col lo St. Mill, col Lassalle cuoi con tutto quanto d'un certo rilievo e d'una certa importanza produsse l'intelligenza socialista[.] La sua intimità col'Engels resta certamente un enigma psicologico, messo in rilievo dalla circonstanza che i socialisti tedeschi hanno sempre evitato di pubblicare una biografia di Marx."

1) Da notare: Marx era molto povero ed Engels molto ricco. Inoltre Engels lasciò eredi della sua fortuna proprio le figlie le di Marx. Arturo Labriola. La "commune" di Parigi. s. 71-72.

Genosse Labriola hat überhaupt sein Buch mit forcirter Originalität verdorben. Er will partout Entdeckungen machen obgleich alle allgemeinen Gesichtspunkte seines neuesten wie früheren Buches vom Georg Sorel stammen. Ich glaube aber dass hier hat seine Originalitätssucht jede Grenzen passiert[.] Wenn ich Ihnen geehrter Genosse nicht unerlaubt andringend scheinen werde, so werde ich sie noch mit einer persönlichen Bitte belastigen. Ich arbeite an einem kleinen Werk über die Philosophie von Karl Marx[.] Leider muss ich Gesundheit wegen in schlimmsten Bücherbedingungen arbeiten[.] So, habe ich bisher keine Möglichkeit gefunden mir Aufsatz von Marx über Max Stirner zu verschaffen[.] Die Buchhandlungen antworten mir, dass es nicht kauflich ist. Da es meine Arbeit, die erste in unserer armen theoretischen Literatur dem grossen Gegenstande sein wird, so vollkommen informiert sehen möchte, als es für mich möglich ist, so macht mir der Mangel dieser Marx'schen Arbeit grosse Sorge. Wenn Sie so freundlich gegen einen Unbekannten sein wollten und mir den Aufsatz zu leihen, würde ich Ihnen sehr dankbar sein und den Aufsatz in einer Woche wiederschicken. Natürlich ist es meinerseits fast eine Frechheit Ihre kostbare Zeit so in Anspruch zu nehmen und ich bin nicht so romantisch um zu sagen Marx'ens willen thun Sie das. Vielleicht werden Sie es aber meiner polnischen Leser willen es thun und damit unendlich verpflichten Ihren Sie hoch verehrenden Genossen

Stanislaus Brzozowski

Nervi. pension Bismarck (Leider! sogar in Italien lebt man in seinem Zeichen)“10

${ }^{10}$ Stanisław Brzozowski to Karl Kautsky, Nervi, 8 June, 1907 (IISH Kautsky D VI 714). I am thankful to Dr. Till Schelz-Brandenburg for his help in finding the original 
Highly esteemed comrade!

Yesterday I received the copy of Die Neue Zeit where my article is published that which my good friend comrade Dr. Salomea Perlmutter had the kindness to translate and send to you. I am glad that my work was judged so benevolently by you and I hope that other of my contribution will from time to time appear on the columns of Die Neue Zeit. If I now permit myself to spoil your time with my letter written in bad German, than I do it in order to point your attention to a detail which maybe is not unworthy of a review and discussion in Die Neue Zeit. In Arturo Labriola's new book about the Paris Commune I found the following "witty" idea about Karl Marx. I copy the passage literally:

However Marx's judgment is put into question. Marx never loved his socialist rivals, the reason of which is the undisputed superiority of his sovereign and an unpleasant spiritual penchant. Successively he broke with Willich, with Weitling, with Proudhon, with Bakunin, with St. Mill, with Lassalle, and with everything produced by the socialist intelligentsia that was of a certain importance and certain renown. His intimacy with Engels will surely remain a psychological mystery, still increased in importance by the fact that the German socialists have always avoided publishing a biography of Marx.

1) Note: Marx was very poor and Engels very rich. Moreover Engels made Marx's daughters heirs of his fortune. Arturo Labriola. The Paris "Commune". Pp. 71-72.

Comrade Labriola generally spoilt his book by excessive originality. He wants to make discoveries at any cost although all general ideas of his recent and his earlier book are indebted to Georges Sorel. I believe his obsession for originality has exceeded all limits here. Hoping not to seem impermissibly intrusive, I would like to bother you with a personal demand. I am working on a small piece on Karl Marx's philosophy. For now I have not yet found an opportunity to purchase Marx's article about Max Stirner. The bookshops have been telling me that it cannot be bought. Since I would like to have my first work, the first in our poor theoretical literature devoted to this great topic, as well informed as possible for me, the lack of this work of Marx is a cause of great concern for me. If you could be so friendly to an unknown person and lend me the article, I would be very grateful and send the article back in a week's time. Of course it is impertinence from my part to take up your precious time and I am not so romantic to say that you will do this for the sake of Marx. Perhaps you will do it for the sake of my Polish readers and infinitely indebt your highly admiring you comrade Stanislaus Brzozowski

Nervi. Pension Bismarck (Unfortunately! Even in Italy one lives in his sign) ${ }^{11}$

copy and for his critical remarks on the first draft of this paper. The transcription of this letter in the edition of Brzozowski's correspondence is riddled with incorrect readings and thus unsuitable for scholarly use (Brzozowski 1970. Vol. 1. 375-377).

${ }^{11}$ As Brzozowski says himself, the letter is written in clumsy and faulty German language. Our translation tries to render this style without reproducing the errors. 
The letter's poor German probably did not create a favourable impression as Brzozowski colloquially addresses Kautsky and Arturo Labriola, a renowned mastermind of socialism, as comrades despite the fact that he had never met either of them. Even Perlmutter, who was herself well-known in the movement, addressed her letters to Kautsky quite formally. It was also a failure because Brzozowski, speaking mainly about himself, used a great number of expressions of submission to Kautsky; his reverence was an odd discrepancy with the oversized intellectual ego of the ambitious Brzozowski. Apparently, Brzozowski believed that Kautsky had a high opinion of his article and he subsequently vowed to send more. He then denounces Labriola for plagiarism and finally, he shares his idea for writing a ground-breaking work on Marx that would be a first "in our poor theoretical literature." He as well assures Kautsky of many more theoretical contributions on Marx and Marxism but also tries to borrow an article by Marx from him. Kautsky left this letter unanswered.

The tone of the letter is quite contrary to his sharply critical tone when Brzozowski wrote about German Social Democracy in February and April 1907. (Stanisław Brzozowski to Wula and Rafał Buber, Nervi, 18 February, 1907 and Nervi, beginning of April, 1907. Brzozowski 1970. Vol. 1. 307-308; 312-316.) It appears that the publication of his article in Germany affected him so strongly that he had a sudden urge to endorse the theoretical side of the German Social Democratic movement. This gesture, however, was most likely insincere since he had already declared himself a non-Marxist (at least from an orthodox perspective) at the beginning of April 1907. Therefore, he must have written the article in question as an outsider, not as an engaged Social Democrat: "Sooner or later what is true must come to light, although I am not a Marxist and I do not possess a redemptive belief in the providence of a silent evolution of economic factors" (Prędzej czy później to, co jest prawdziwe, wydobędzie się, chociaż nie jestem marksistą i zbawiającej wiary w opatrzność milczącej ewolucji czynników ekonomicznych nie posiadam). (Stanisław Brzozowski to Wula and Rafał Buber, Nervi, beginning of April, 1907 Brzozowski 1970. Vol. 1. 314-315.)

In any case, once the article was published, Brzozowski thought that he was welcomed by the Social Democrats, so much so that he was thinking about going to Stuttgart for the 18-23 July Congress of the Socialist International (like his friend Buber; Najdus 1980. 133). Additionally, he considered sending another article to the review Mouvement Socialiste (Socialist Movement). (Stanisław Brzozowski to Wula and Rafał Buber, Nervi, the first ten days of July, 1907. Brzozowski 1970. Vol. 1. 372-373.) His rather poor opinion of the Germans and German Social Democrats had by no means changed after the publication of his article, but it only turned even more bitter when he received no answer from Karl Kautsky. Around mid-November 1907 he wrote about bestialità tedesca (German bestiality) and vented his ambitiously destructive plans to criticize the position of the Stuttgart Congress and to prove in general that "socjaldemokrac- 
ja niemiecka niezasłużenie zajmuje przodujące miejsce pośród organizacji socjalistycznych świata". (German Social Democracy is undeservedly occupying the leading position among the socialist organizations in the world.) (Stanisław Brzozowski to Wula and Rafał Buber, Florence, mid-November, 1907. Brzozowski 1970. Vol. 1. 394, 398n21.)

\section{Brzozowski's German Publication in the Context of the Polish Social Democratic Movement}

Brzozowski's aim for the article's publication was not only to gain German readers but he also wanted to flaunt his success to his fellow Polish Social Democrats (he had a complicated relationship with many of them). Although the article had already been printed in Polish, the fact that it was translated and published in German would raise Brzozowski's standing within Polish Social Democracy. Not only were Brzozowski's relations to Polish Social Democracy complicated, ${ }^{12}$ the labour movement itself was in a precarious situation because Poland was partially controlled by the Austro-Hungarian Empire (Blobaum 1984; Hawranek 1977; Kochański 1971; Kormanowa 1958; Makowski 1991; Najdus 1980; 1983; Orzechowski 1978; Tymieniecka 1918; Żarnowska 1965). The labour movement in the German-occupied territories in Brzozowski's time consisted of the Polska Partia Socjalistyczna zaboru pruskiego (PPS zp), which had seceded from the German Socialist Party (SPD) in 1901, and the Polska Partia Socjaldemokratyczna Galicji (PPSD), which operated in Austro-Hungarian Galicia.

Brzozowski associated more with the PPSD because Perlmutter and Buber, who were working in Jewish socialist organizations that were associated with the party on varying degrees, were his contacts in the party. Eventually, Brzozowski published some of his own material in the party's journal (Najdus 1983. 510). Brzozowski did have problems though with the two parties who later formed the Polish Communist Workers' Party in 1918. Socjaldemokracja Królestwa Polskiego i Litwy (SDKPiL) (Social Democracy of the Kingdom of Poland and Lithuania) operated in the Russian territories and they had a more orthodox platform, which meant that they were Brzozowski's enemies. Their newspaper, Czerwony Sztandar (Red Flag), reported on Brzozowski's alleged espionage scandal in early 1908 partly because of his criticism of Rosa Luxemburg, ${ }^{13}$ who was the party's most well-known member, and because of his opinion that Polish

12 Stanisław Brzozowski to Rafał Buber, Florence, 7 Mai, 1908 (Brzozowski 1970. Vol. 1. 502-503). Kochański 1971. 274-275; Walicki 2011b. 187-194.

${ }^{13}$ See Stanisław Brzozowski to Wula and Rafał Buber, Nervi, 28 January, 1906 (Brzozowski 1970. Vol. 1. 136). 
philosophy was greater than Marxism (Walicki 2011b. 51-53). Polska Partia Socjalistyczna (PPS) (Polish Socialist Party), on the other hand, valued Poland over Marxism and thus PPS's position was closer to that of Brzozowski; they regarded him more as a rival than an enemy (Sroka 1970. xxxi). During the Russian Revolution of 1905, Brzozowski was a sympathizer of the PPS (Żarnowska 1965. 34), and he took the position of official journalist and theorist for the PPS the following year (Walicki 2011b. 194-195). In the early 1930s Robotnik (The Worker), the party's paper, had a more lenient perspective of the Okhrana affair (Niedziałkowski 1933). At any case, the publication in Germany did not improve Brzozowski's positions among Polish Social Democrats.

\section{An Echo of Brzozowski's Article: Max Adler's Das Formalpsychische im historischen Materialismus}

Kautsky decided to publish Brzozowski between the renowned Marxists, Rudolf Hilferding and Franz Mehring, which may reflect Kautsky's reservations about Brzozowski as the two were perfect foils for Brzozowski's unorthodox views. Brzozowski would never be published again in Die Neue Zeit after his letter to Kautsky, but they did publish an article thoroughly refuting his position without mentioning his name. Soon after Brzozowski's article was published, Max Adler issued his Das Formalpsychische im historischen Materialismus (The Formal Psychical in Historical Materialism), which gave an overview to the theoretical approaches that were printed in Die Neue Zeit. ${ }^{14}$ Adler gives some details on the international repercussions of Brzozowski's writing. Unfortunately, scholarship has taken into account nearly exclusively Anatolii Lunacharskii's reflections on Brzozowski. ${ }^{15}$

14 "Das Grundproblem der materialistischen Geschichtsauffassung ist die Frage nach dem Verhältnis des Materiellen zum Ideellen, nach der Art der zwischen beiden bestehenden Beziehung. Es wäre jetzt, da diese Zeitschrift auf ein Vierteljahrhundert unermüdlicher Arbeit an den theoretischen Grundanschauungen des Sozialismus zurückblickt, nicht blos naheliegend, sondern auch sehr lohnend, der Geschichte der Weiterbildung des historischen Materialismus an den Blättern der „Neuen Zeit“" nachzugeben. Hat sie doch mit vielen bedeutungsvollen Abhandlungen in diese Weiterentwicklung eingegriffen; ich erinnere nur an die Aufsätze von F. Mehring zu diesem Thema, an die Arbeiten von H. Cunow und Sadi Gunter, vor allem aber an die Artikelserie von K. Kautsky im XV. und von Max Zetterbaum im XXI. Jahrgang dieser Zeitschrift.” (Adler 1908 52.) Among others, Adler must have had the articles in mind as follows: Mehring 1894; Mehring 1899a; 1899b; Cunow 1899; Gunter1898; Kautsky 1895; Kautsky 1896; Kautsky 1899; Zetterbaum 1903b.

${ }^{15}$ Łunaczarski 1969. Vol. 3. 853-864. For the monistic theory of history, see Walicki 2011a. 44. For Brzozowski's acquaintance with Lunacharskii, see Stanisław Brzozowski 
From Adler's retrospective account, it seems that Brzozowski's provocative study helped end the debate on historical materialism in Die Neue Zeit and it paradoxically contributed to the consolidation of the orthodox interpretation to Marxism. Adler considered the orthodox interpretation of the base and superstructure as a dogma that was not open to revision. ${ }^{16}$ Criticizing this position was nothing else than a bourgeois chimaera, "[a]uch seither hat kaum ein Marxist von wissenschaftlicher Bedeutung eine derart skurrile Ansicht vertreten, und alle bürgerliche Polemik gegen dieses Phantom ist pures Mißverständnis" (never before has any Marxist of some scientific reputation held such a bizarre view, and all the bourgeois polemics against this ghost is a pure misunderstanding), (Adler 1908. 53). This statement applied to Brzozowski's argument meant that Brzozowski was "no Marxist of scientific significance" and his critique was a bourgeois polemic directed against phantoms that originated from a misunderstanding. Adler's response to Brzozowski's attack (or one much like it) was that historical materialism is essentially related to real life and it has nothing to do with materialism in natural philosophy (Adler 1908. 54). In connection with this, Adler refuted the Hegelian readings of Marx, (Adler 1908. 55) and then his summarizing statement on the nature of art and ethics seem to reject Brzozowski's viewpoint,

die bewußt gewordenen Richtmaße unserer geistigen Natur, also die Ideen der Wahrheit, der Sittlichkeit, des Rechtes, der Kunst, sind somit nichts anderes als die Formen der sozial gewordenen Selbsterhaltung, als die Art, in welcher sich die soziale Beschaffenheit des menschlichen Lebens inmitten seines individuellen Entwicklungsprozesses immer wieder herstellt.

to Salomea Perlmutter, Florence, beginning of December, 1907 (Brzozowski 1970. Vol. 1. 409). For Lunacharskii's critique, see Walicki 1974. 214-219; Mänicke-Gyöngyösi 1982. 222; Politt 1996. 91. In Holger Politt's interpretation, Lunacharskii's main objection was directed towards Brzozowski's all-too Hegelian stance in which the Marxist position was hardly recognizable. According to Politt, Brzozowski failed to understand Lunacharskii's response and mistook it for a sign of approval. See also: Brzozowski 1970. Vol. 1. 401.

16 "Die materialistische Geschichtsauffassung bestimmt das Verhältnis des Ideellen zum Materiellen in der Weise, daß sie bekanntlich das letztere zum bedingenden oder, wie der Ausdruck auch lautet, bestimmenden Element des ersteren macht." This is a thesis that Marx as well as Engels held (i.e., Adler defended Engels against any revisionist attack): "Die Unterstellung, als ob die materialistische Geschichtsauffassung je behauptet hätte, das Materielle, das heißt die ökonomischen Lebensverhältnisse bewirken oder erzeugen erst die geistigen Lebensformen, so daß also diese in Idee, Sitte, Recht, Kunst usw. nur eine Art von Reflex wären, ohne jede eigene, selbständige Wesenheit erscheint schon durch den Wortsinn der bezüglichen Stellen bei Marx und Engels widerlegt." (Adler 1908. 53.) 
The standard gauges of our spiritual nature, hence the ideas of truth, morality, rights, and art are nothing else than forms of self-preservation having become social, than the way in which the social shape of human life is constantly reproducing itself in the middle of its individual process of development. (Adler 1908. 58.)

It was in this sense that Adler rejected Prometheism as well as determinism, the sphere of economy is nothing else but the fundamental layer of the spiritual and thus the "superstructure" can never be independent of the "base" even less can their relation be reversed (Adler 1908. 60).

\section{Conclusion}

Brzozowski's efforts to make a name outside of the Polish-speaking world peaked in the first half of 1907 when his position was close enough to Marxism that he looked for contacts with the Austrian and German Social Democrats. But jealousy limited his ambition, because he wanted to stand on a more equal footing with the Polish Social Democratic leaders who had urged him to seek support and recognition in the German-speaking world. In his haste to be known, Brzozowski unwittingly (or deliberately?) reversed his priorities-being an author in Die Neue Zeit did not make a Social Democrat but instead it was being an engaged Social Democrat that made on an author of the journal. Brzozowski's publication in Die Neue Zeit was an exception and the reasons for his appearance in the journal remain a mystery.

At first it seemed that he was about to realize his dream: two of his articles were published in Perlmutter's translation, but it did not come to anything and it was very much his loss. The letter he wrote to Kautsky delivered the coup de grâce to their possible personal, political, or professional relations. Adler's devastating rectification concerning the "correct" interpretation of historical materialism, Luxemburg's denunciation of Brzozowski at Der Kampf, and the accusations of his being a collaborator with the Tsarist Okhrana (Brzozowski 1970. Vol. 1. 487n7; Kochański 1971. 22-23) swept all of his hopes away of gaining a greater intellectual reputation in a national and international context. These accusations finally alienated Brzozowski from the Polish Social Democrats and he also maintained resentment against the German Party (Walicki 2011a. 191-193) most likely because of the negative reception of his article and the rejections of anymore of his work. 


\section{References}

Archives Sources

Bundesarchiv (BArch), Germany. Nachlass Karl Kautsky (= BArch Kautsky).

International Institute of Social History, Amsterdam, the Netherlands. Karl Kautsky Papers (= IISH Kautsky).

\section{Bibliography}

Adler, Max 1908. Das Formalpsychische im historischen Materialismus. Die Neue Zeit. 26(1)/2. 52-61.

Blobaum, Robert 1984. Feliks Dzierżyński and the SDKPiL: A Study of the Origins of Polish Communism. New York, Columbia University Press.

Brzozowski, Stanislaus 1907. Der Geschichtsmaterialismus als Kulturphilosphie: Ein philosophisches Programm. Die Neue Zeit. 25(2)/31. 153-60.

Brzozowski, Stanisław 1920. Flammen. Vol. 1-2. Eine berechtigte Übertragung aus dem Polnischen von Leon Richter. Berlin, Bong.

Brzozowski, Stanisław 1970. Listy [Letters]. Vol. 1-2. Ed. Mieczysław Sroka. Kraków, Wydawnictwo literackie.

Cunow, Heinrich 1899. Ein Kritiker der materialistischen Geschichtstheorie. Die Neue Zeit. 17(2)/45. 584-595.

Emig, Brigitte - Max Schwarz - Rüdiger Zimmermann 1981. Literatur für eine neue Wirklichkeit. Bibliographie und Geschichte des Verlags J. H. W. Dietz Nachf. 1881 bis 1981 [Literature for a New Reality: Bibliography and History of the Publishing House J. H. W. Dietz Nachf. 1881-1981]. Berlin, Dietz.

Gorny, Josef 2002. „New man's land.” Review of 'Ha'adam Hahadash' Shel Hamahapekha Hatzionit: Hashomer Hatzair Veshorshav Ha'eropayim (The 'New Man' of the Zionist Revolution: Hashomer Hatzair and its European Roots), by Rina Peled. Haaretz. November 15. http://www.haaretz.com/new-man-s-land-1.28337

Graf, Angela 1998. J. H. W. Dietz 1843-1922. Verleger der Sozialdemokratie [J. H. W. Dietz 1843-1922: Publisher of Social Democracy]. Bonn, Verlag von J. H. W. Dietz Nachfolger.

Gunter, Sadi 1898. Die materialistische Geschichtsauffassung und der praktische Idealismus. Die Neue Zeit. 16(2)/41. 452-464.

Hawranek, Franciszek 1977. Polska i niemiecka socjaldemokracja na Górnym Ślasku w latach 1890-1914 [Polish and German Social Democracy in Upper Silesia in the Years 1890-1914]. Opole, Instytut Śląski.

Kautsky, Karl 1895. Darwinismus und Marxismus. Die Neue Zeit. 13(1)/23. 708-718

Kautsky, Karl 1896. Die materialistische Geschichtsauffassung und der psychologische Antrieb. Die Neue Zeit. 14(2)/47. 652-659.

Kautsky, Karl 1899. Bernstein und die materialistische Geschichtsauffassung. Die Neue Zeit. 17(2)/27. 4-16.

Kautsky, Karol 1906a. Etyka w świetle materjalistycznego pojmowania historji. Szkic [Ethics in the Light of a Materialist Concept of History. A Sketch]. Z upoważnienia autora tłumaczył A. Warski. (Bibljoteka naukowa). Warszawa, Wyd. St. Kucharskiego.

Kautsky, Karl 1906b. Ethik und materialistische Geschichtsauffassung. Stuttgart, Verlag von J. H. W. Dietz Nachfolger. 
Kempe, Frank C. s. a. Galerie Saxonica.

http://www.saxonia.com/cgi-bin/dynfs.pl?Kuenstler_liste=/galerie/008619.htm

Kochański, Aleksander 1971. Socjaldemokracja Królestwa polskiego i Litwy w latach 1907-1910 [Social Democracy of the Kingdom of Poland and Lithuania in the Years 1907-1910]. Warszawa, Książka i Wiedza.

Kormanowa, Żenna 1958. Kwestia narodowa w rewolucji 1905-1907 roku [The National Question in the 1905-1907 Revolution]. Warszawa, Wiedza Powszechna.

Kwestja polska a ruch socjalistyczny 1905. Zbiór artykułów o kwestji polskiej R. Luxemburg, K. Kautsky'ego, F. Mehringa, Parvusa i innych z przedmowa R. Luxemburg $i$ uwagami wydawców oraz dodatkiem [The Polish Question and the Socialist Movement: A Volume of Studies on the Polish Question by R. Luxemburg, K. Kautsky, F. Mehring, Parvus and Others, with a Foreword by R. Luxemburg, with Remarks by the Publishers, and with an Appendix]. Kraków, Rudolf Moszoro (= Kwestia 1905).

Leszczawski-Schwerk, Angelique 2014. "Die umkämpften Tore zur Gleichberechtigung:" Frauenbewegung in Galizien. Berlin, LIT Verlag.

Łunaczarski, Anatol 1969. Stanisław Brzozowski a materializm dziejowy [Stanisław Brzozowski and Historical Materialism]. In Pisma wybrane [Selected Writings]. Trans. Adam Galis et al.; introduction and notes by Leszek Turek. Warszawa, Książka i Wiedza. Vol. 3. 853-864.

Makowski, Edmund 1991. Od socjaldemokracji do "solidarności”. Organizacje robotnicze w Wielkopolsce w XIX i XX wieku (do roku 1990) [From Social Democracy to "Solidarity:" Workers' Organizations in Great Poland in the $19^{\text {th }}$ and $20^{\text {th }}$ Century (to the year 1990)]. Poznań, Wydawnictwo Naukowe UAM.

Mänicke-Gyöngyösi, Krisztina 1982. „Proletarische Wissenschaft” und „, sozialistische Menschheitsreligion" als Modelle proletarischer Kultur ['Proletarian Science' and 'Socialist Religion of Humankind' as Models of Proletarian Culture]. Wiesbaden, Harrassowitz.

Mehring, Franz 1894. Zur historisch-materialistischen Methode. Die Neue Zeit. 12(2)/31. $142-148$.

Mehring, Franz 1899a. Vom “wahren” Marxismus. I-II. Die Neue Zeit. 18(1)/3. 86-89; 18(1)/4. 118-122.

Mehring, Franz 1899b. Ein letztes Wort über den "wahren” Marxismus. Die Neue Zeit. 18(1)/9. 280-283.

Najdus, Walentyna 1980. SDKPiL a SDPRR 1908-1918 [Social Democracy of the Kingdom of Poland and Lithuania and the Russian Social Democratic Workers' Party 1908-1918]. Wrocław, Zakład narodowy Imienia Ossolińskich - Wydawnictwo Polskiej Akademii Nauk.

Najdus, Walentyna 1983. Polska Partia Socjalno-Demokratyczna Galicji i Ślaska 18901919 [The Polish Social Democratic Party in Galicia and Silesia, 1890-1919]. Warszawa, Państwowe Wydawnictwo Naukowe.

Niedziałkowski, Mieczysław 1933. Sprawa Stanisława Brzozowskiego [The Brzozowski Issue]. Robotnik. 265. [1].

Nordheimer-Nur, Ofer 2009. Die anarchistische Ästhetik der Jugendbewegung 'HaShomer HaZa'ir' in den 1920er Jahren und das Tragische in ihrer Weltanschauung. In Deutsch-Jüdische Jugendliche im “Zeitalter der Jugend.” Edited by Yotam Hotam. Göttingen: Vandenhoeck \& Ruprecht. 61-74. 
Oppenheimer, Aharon 2004. Matityahu Mintz at 80. SHVUT. Studies in Russian and East European Jewish History and Culture. (2002-2003) 27/11. (Matityahu Mintz Jubilee Volume. Edited by Benjamin Pinkus. Tel Aviv, Tel Aviv University). 9-13.

Orzechowski, Marian 1978. Rewolucja, socjalizm, tradycje. Przeszłość narodowa $i$ tradycje w myśli politycznej rewolucyjnego nurtu polskiego ruchu robotniczego [Revolution, Socialism, Traditions: National Past and Traditions in the Political Thought of the Revolutionary Current of the Polish Workers' Movement]. Warszawa, Książka i Wiedza.

Perlmutter, Dr. Salomea 1903. Tolstois Weltanschauung und ihre Entwicklung. Die Neue Zeit. 21(1)/13. 404-407.

Perlmutter, Dr. Salomea 1905. Ein Beitrag zur Agrarfrage. I - II. Die Neue Zeit. 23(2)/27. 20-27; 23(2)/28. 5459.

Politt, Holger 1996. Stanisław Brzozowski: Hoffnung wider die dunkle Zeit [Stanistaw Brzozowski: Hope Against Dark Time]. Wiesbaden, Harrassowitz.

Schelz-Brandenburg, Till. Introduction to Die Neue Zeit. Online-Edition der Bibliothek der Friedrich-Ebert-Stiftung. http://library.fes.de/nz/nz-intro.html

Sroka, Mieczysław 1970. Introduction to Stanisław Brzozowski. Listy. Kraków: Wydawnictwo Literackie. Vol. 2. VII-LXXX.

Tych, Feliks 1992. Karl Kautsky und die polnische Frage. Aus dem Polnischen von Jürgen Hensel. In Marxismus und Demokratie. Karl Kautskys Bedeutung in der sozialistischen Arbeiterbewegung. Edited by Jürgen Rojahn - Till Schelz - Hans-Josef Steinberg. Frankfurt: Campus Verlag. 274-286.

Tymieniecka, Aleksandra (ed.) 1918. Manifest zjazdu zjednoczeniowego SDKPiL i PPSLewicy [The Manifesto of the Unification Meeting of SDKPiL and Left-PPS]. Lublin, Wydawnictwo Lubelskie.

Walicki, Andrzej 1974. Stanisław Brzozowski i rosyjscy 'neomarksiści' początku XX wieku. In Wokót myśli Stanisława Brzozowskiego. Edited by Andrzej Walicki - Roman Zimand. Kraków, Wydawnictwo Literackie. 195-219.

Walicki, Andrzej 2011a. Stanisław Brzozowski - drogi myśli [Stanisław Brzozowski: Paths of Thought]. Kraków, Universitas.

Walicki, Andrzej 2011b. Brzozowski i zagadnienie "zachodniego marksizmu". In Stanisław Brzozowski - drogi myśli. Kraków, Universitas. 365-367.

Żarnowska, Anna 1965. Geneza rozłamu w Polskiej Partii Socjalistycznej 1904-1906 [The Origins of the Schism in the Polish Socialist Party 1904-1906]. Warszawa, Państwowe Wydawnictwo Naukowe.

[Zetterbaum, Max] mzm 1903a. Dr. Salomea Perlmutter, "Karl Menger und die österreichische Schule der Nationalökonomie“. Die Neue Zeit. 21(1)/8. 254-255.

Zetterbaum, Max 1903b. Zur materialistischen Geschichtsauffassung. Die Neue Zeit. 21(2)/43. 524-531. 